\title{
Article \\ GIS in Architectural Teaching and Research: Planning and Heritage
}

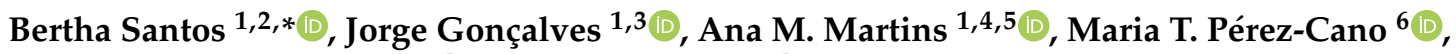 \\ Eduardo Mosquera-Adell ${ }^{7}$, Despina Dimelli ${ }^{8}$ (D), Apostolos Lagarias ${ }^{9}$ and Pedro G. Almeida ${ }^{1,10}$
}

Citation: Santos, B.; Gonçalves, J.; Martins, A.M.; Pérez-Cano, M.T.; Mosquera-Adell, E.; Dimelli, D.; Lagarias, A.; Almeida, P.G. GIS in Architectural Teaching and Research: Planning and Heritage. Educ. Sci. 2021, 11, 307. https://doi.org/ 10.3390/educsci11060307

Academic Editor: James Albright

Received: 27 May 2021

Accepted: 15 June 2021

Published: 21 June 2021

Publisher's Note: MDPI stays neutral with regard to jurisdictional claims in published maps and institutional affiliations.

Copyright: (c) 2021 by the authors. Licensee MDPI, Basel, Switzerland. This article is an open access article distributed under the terms and conditions of the Creative Commons Attribution (CC BY) license (https:// creativecommons.org/licenses/by/ $4.0 /)$.
1 Department of Civil Engineering and Architecture, University of Beira Interior, 6200-358 Covilhã, Portugal; jorge@ubi.pt (J.G.); amtfm@ubi.pt (A.M.M.); galmeida@ubi.pt (P.G.A.)

2 CERIS, Instituto Superior Técnico, Universidade de Lisboa, 1049-001 Lisbon, Portugal

3 CITTA, Department of Civil Engineering, University of Coimbra, 3030-788 Coimbra, Portugal

4 Lab2PT, Instituto de Ciências Sociais, Universidade do Minho, Campus de Gualtar, 4710-057 Braga, Portugal

CIDEHUS, Universidade de Évora, 7000-809 Évora, Portugal

6 Department of Urbanistics and Land Management, School of Architecture, University of Seville, 41012 Seville, Spain; tpcano@us.es

7 Department of History, Theory and Architectural Composition, School of Architecture, University of Seville, 41012 Seville, Spain; emosquera@us.es

8 School of Architecture, Technical University of Crete, 73100 Chania, Greece; dimelli@arch.tuc.gr

9 Institute of Applied and Computational Mathematics, Foundation for Research and Technology, 70013 Heraklion, Greece; lagarias@iacm.forth.gr

10 GEOBIOTEC, Department of Civil Engineering and Architecture, University of Beira Interior, 6200-358 Covilhã, Portugal

* Correspondence: bsantos@ubi.pt

Abstract: Geographical Information Systems (GISs) in architecture were initially limited to regional and urban development applications. Over recent years its potential has been recognized and its use has evolved to address urban planning and architectural heritage management subjects. Nevertheless, evidence shows that its use in architecture teaching is scarce and uneven. Directive 2007/2/EC, establishing the infrastructure for spatial information in the European Community (EU), is, in this way, an opportunity to develop a greater knowledge and application of GIS in the framework of higher education. In architecture, this can be achieved by problem solving based on real case scenarios, which can benefit from GIS-based techniques and analysis capabilities. In this paper, the authors aim to present a review of the use of GIS in teaching and research in architecture to assess its level in different European programmes. Experiences from three European universities (University of Seville, Spain, University of Beira Interior, Portugal, and Technical University of Crete, Greece), which are among the few in their respective countries that promote the inclusion of GIS in architectural education, particularly in the fields of urban and regional planning and architectural heritage, are compared and framed within the European scenario. The paper concludes with a reflection on the three universities' practice compared to the leading European architecture programmes listed in the main international university rankings. Main trends of future evolution on the use of GIS in architecture teaching are also presented.

Keywords: architecture; teaching and research; geographical information systems (GISs); heritage; urban and regional planning

\section{Introduction}

According to Drennon [1], non-geographers are probably the fastest-growing group of GIS users. In the field of architecture, some authors have shown [2] the relevance of personalities such as Frank Lloyd Wright (1867-1959), Richard Neutra (1892-1970), Warren Manning (1860-1938) and Ian McHarg (1920-2001) as geodesigners avant la lettre when 
considering geographic contexts and existing environmental conditions to develop some of their designs.

In architecture, GIS was initially used for regional and urban development and then extended to urban planning and management, offering architects more than just base maps and site diagrams. It encompasses various scales of subjects and space, incorporating powerful tools for the analysis, design, production and management of architecture data to support informed decisions [3,4].

Presently, the amount of information available in geobrowsers (such as Google Earth) and geodata portals shifted the modern world from a place where spatial information was difficult to find to one that is overwhelmed with geographically referenced data. GIS can be a powerful tool to process this data for architectural purposes.

For the last two decades, GIS technology has evolved as a working tool for architects and spatial planners, specifically by overcoming the difficulties related to the organisation of available digital spatial information and data from photogrammetry and 3D laser scanning [5]. From another perspective, Freire [6] also stressed the relatively low cost as one of the main advantages of the use of GIS analysis on large-planning architectural projects, making it a fundamental tool for low-budget studies in lower-income countries with high-value information output.

This paper aims to carry out a review of the use of GIS in teaching and research in architecture, with special emphasis on its use in the fields of urban and regional planning and architectural heritage to assess the level of GIS teaching in European architecture programmes. The leading European universities in reference education rankings are analysed, and the experience of the University of Seville (Spain), University of Beira Interior (Portugal) and Technical University of Crete (Greece) is presented and compared with the European scenario. These three universities have a history of research and Erasmus + partnership and are among the few that teach and use GIS in architectural education in their respective countries. The paper concludes with a reflection on the GIS education level in architecture programmes, lessons obtained from teaching and research experience, highlighting the main evolution trends in the use of GIS in architecture education.

\section{GIS in Architecture Education and Research}

According to Schulze et al. [7] information-based society and increased workforce mobility in globally competitive labour markets shifted the focus of educational processes from an input orientation to learning outcomes, defining "competence" as a key concept for twenty-first-century skills. The development of competence-based curricula in European higher education was influenced by the Bologna reform and the creation of a common European higher education area with comparable degrees of undergraduate and graduate study programmes. In this context, the Bologna process has defined "competence" as the fundamental change towards a student-centred focus and outcomes-based on a lifelong learning process. This process has also emphasized the student's preparation for professional environments. In Spain and Portugal, this process has already been adopted; still, in the Greek case, the Bologna reform is not yet implemented, and thus Greek universities only have one degree that is not split into undergraduate and graduate study programmes (4 years long for universities and 5 years for technical universities).

In both scenarios, higher education institutions struggle to make a difference distinguishing themselves and thus competing for students, partly because goals, activities and curricula are often quite similar [8].

While the redefinition of generic skills was implemented mainly due to societal concerns, the identification of professional competences depends on the demands of subject-specific knowledge and skills in specific domains. Among these specific skills, the so-called twenty-first-century skills are highlighted, commonly referred to as ICT literacy. These skills generally require a lifelong learning process that includes digital and technical mastery; problem solving; critical thinking; communication; and collaboration [7]. 
As stated by Sinton [8], GIS-based projects and courses can be a response to this challenge supporting the educational goals and activities while being integrated into diverse curricula. GIS is an ICT tool that allows students to explore real-world spatial data and engage them in the toolmaking processes of revising databases, formulating modes of display and representation and developing methods of analysis and interpretation translated in a learning environment proved to be active, flexible, responsive to student questioning and, ultimately, empowering in critical spatial thinking [9,10] and research directions [11]. Furthermore, according to Hwang [10], the different paths of data acquisition, organization and presentation in GIS are conducive to promoting a common understanding of complex problems among different stakeholders.

Considering the architecture teaching curricula, during the last two decades, the integration of digital technologies has increased throughout the training of thinking and making of space, both in dedicated curricular units such as computer-aided design (CAD) and geographic information system (GIS), or in cooperation with later year courses, including the final dissertation/project [12,13]. According to Kara [14], the various technologies of computing-aided drafting, enumerating, modelling and analysis started to shape the overall curricular structure of architecture education and need to be implemented as support courses in order to compensate for the learning curve and the variety of software available to architects.

Typically, GIS is taught as a compulsory part of a wider study-skills module in the first years of the course. After that, it is presented as a module, usually as an optional subject, aimed to develop technical skills associated with a specific GIS package. However, it often lacks wider integration.

Despite the many possible applications and advantages, architects adopting GIS techniques, either in practice or research, are still scarce. Monsur and Zakiul [3] and Pinto Puerto et al. [4] stated that most of the architecture learning curricula all around the world have little or no GIS contents, and most of those that incorporate GIS courses lack the conceptual connection with traditional architectural subjects. This connection is crucial to establish the use of GIS in architecture education and to promote a "problem-evaluation -solution" loop teaching approach [6,12]. In this context, Ferreira-Lopes [15] pointed out that the reason for the limited use of GIS capabilities in cultural heritage may be related to the lack of training and professional updating, which was also corroborated by Blišt'an et al. [16] for the teaching of GIS in general. The need for new research is also highlighted, especially focused on the GIS analysis tool potential.

Simultaneously, there has been a tendency to use GIS to solve more specific problems of architectural heritage, urban design and planning through its use in conjunction with other tools and techniques such as BIM [4,17]; 3D and photogrammetry [18-21]; virtual reality [22]; multi-criteria assessment [23]; and web applications. The reduced investment in software and maintenance costs and broader accessibility and interaction between users and GIS are some of web applications' characteristics that enhance the dissemination of GIS use in architectural practice, research and education.

\section{The Role of GIS in Urban and Regional Planning}

Urban and regional planning can be regarded as a means for systematically anticipating and achieving adjustments in the physical environment of a town or rural setting, which must be consistent with social values and sound principles of civic design [24]. According to Faludi [25] and supported by the cybernetic theory, which considers information as of major importance, planning can be constrained as a result of insufficient information. For urban and regional planning, information is a basic tool that defines decision making.

The different stages in the urban and regional planning process can be generalised as the determination of objectives, resource inventory, analysis of existing situations, modelling and projection, development and selection of planning options and plan implementation, evaluation, monitoring and feedback. In these procedures, GIS can provide some of the data and techniques that are needed in different stages of the process. In recent 
decades, GIS has been widely used in urban and regional planning for handling spatial data and supporting decision making. Some examples of the application of GIS in this field are the analysis of development plans, review of environmental impacts, preservation of historic sites, mapping of utility networks and planning for service interruptions.

Many planning departments have shifted to GIS in lieu of mapping software as it is an operational information system for planning with data visualisation and internet potentialities. However, the situation is not homogeneous despite European regulations (Directive 2007/2/EC [26]). In the case of Spain, it is possible to find communities such as Extremadura where there are no schools of architecture but a GIS was implemented for the mandatory management of urban planning with open public access (Extremadura Spatial Data Infrastructure IDEEX). In Andalusia, where there are three public schools of architecture, it is not mandatory for planning instruments to be developed on GIS, nor did the Andalusian Community develop a tool of its own. However, some municipalities such as Seville have developed open geoportals for public urban and planning information. Considering Portugal, several public national and a significant portion of municipal entities have already adopted GIS to support urban as well as regional planning processes. Geoportals that can be accessed by citizens promote the use of information produced by official entities and municipalities and allow to perform operations such as querying geographic data, accessing municipal plans and issuing location charts. SNIG, SIG Portal Regional do Médio Tejo, Geodados (Lisbon Municipality) and Geoportal (Covilhã Municipality) are examples of Portuguese geoportals accessible to citizens. In Greece, during the past ten years, many large cities (Thessaloniki, Heraklion, Trikala, Larisa) along with several smaller municipalities have adopted GISs that support urban and regional planning. All citizens can access municipal geoportals and perceive land uses, building regulations and historic site information as defined in plans and laws. The Greek state has also launched a national geoportal aiming to make all spatial data available through open access sources.

Table 1 presents some examples of Spanish, Portuguese and Greek geoportals that can be used to support urban and regional planning.

According to Stauskis [27], as a virtual urban simulation method for representing, analysing, referring and improving urban design projects, GIS can enhance public participation. GIS, and WebGIS (geoportals and geobrowsers) in particular, is especially useful for participatory planning processes (PPGIS: Public Participation GIS), helping affected social sectors to become empowered by interacting more directly with documents and information produced using GIS.

Table 1. Examples of Spanish, Portuguese and Greek geoportals.

\begin{tabular}{|c|c|c|c|}
\hline Geoportal & Level & Territorial Coverage & $\begin{array}{l}\text { Web Link (All Accessed on January } 11 \\
\text { 2021) }\end{array}$ \\
\hline $\begin{array}{l}\text { IDEE_Spatial Data Infrastructure (SDI) of } \\
\text { Spain }\end{array}$ & National & Spain & https://www.idee.es/web/guest \\
\hline $\begin{array}{l}\text { IDEEX_Extremadura Spatial Data } \\
\text { Infrastructure }\end{array}$ & Regional & Extremadura (Spain) & http://ideextremadura.com/Geoportal/ \\
\hline $\begin{array}{l}\text { IDE Sevilla-Spatial Data Infrastructure of } \\
\text { Sevilla }\end{array}$ & Municipal & Seville (Spain) & https://sig.urbanismosevilla.org/ \\
\hline $\begin{array}{l}\text { SNIG—National Geographic Information } \\
\text { System }\end{array}$ & National & Portugal & https://snig.dgterritorio.gov.pt/ \\
\hline SIG—Regional Portal of Médio Tejo & Regional & Médio Tejo Region (Portugal) & $\begin{array}{l}\text { https: } \\
\text { ///mediotejo.pt/index.php/sig-public }\end{array}$ \\
\hline Geodados_Lisbon City Council Platform & Municipal & Lisbon (Portugal) & http://geodados.cm-lisboa.pt/ \\
\hline Geoportal—Covilhã City Council & Municipal & Covilhã (Portugal) & http://plantasonline.cm-covilha.pt/ \\
\hline $\begin{array}{l}\text { Geodata-Open geospatial data and services } \\
\text { for Greece }\end{array}$ & National & Greece & https://geodata.gov.gr/ \\
\hline $\begin{array}{l}\text { e-ПO } \Lambda \text { EO } \Delta \text { OMIA-Electronic urban } \\
\text { planning GIS }\end{array}$ & National & Greece & http://gis.epoleodomia.gov.gr/ \\
\hline WebGIS-Thessaloniki & Municipal & Thessaloniki (Greece) & https://gis.thessaloniki.gr/ \\
\hline WebGIS-Heraklion & Municipal & Heraklion (Greece) & http://gis.heraklion.gr/ \\
\hline
\end{tabular}


The evolution of GIS and urban and regional planning is thus marked by the interdisciplinary fields of knowledge involved (anthropology, architecture, economics, geography, political sciences and sociology, among others) and by the use of computer engineering, geodesy, geography and photogrammetry, being commonly taught in most countries under geography or geomatics engineering studies [28].

\section{The Role of GIS in Architectural Heritage}

Urban heritage is widely regarded as a primary concern both to today's focused heritage community and to the communities that inhabit these multi-faceted spaces $[29,30]$. The knowledge and the use of heritage are essential elements for their safeguarding, sustainability and evaluation as well as factors of progress in various aspects of development, in particular, when underlining the interdependence between culture and community quality of life [31-34]. The transformation of historic buildings and their subsequent adaptation to contemporary living needs are one of the major concerns in the field of contemporary city construction [33-35].

Due to the heterogeneity of handled information, management of architectural heritage differs from other fields. One of the main problems encountered in the field of historical and architectural research is the absence of a global vision mapping historical phenomena with clear spatiotemporal coordinates [36]. Most municipalities face problems concerning data dispersion among several municipal offices and administrative entities. In most cases, there is no coordination among the different offices, which have different archive systems and lack of digital archives. As a consequence, public entities are not aware of the collected or available data to allow their systematic organization [37].

GIS can be used in different ways to understand architecture in all its complexity connecting it to the cultural, social and historical aspects of a spatial environment, highlighting the usefulness and vast potential for analysing and managing heritage in a multi-disciplinary yet coherent vision $[4,38]$. Such systems can manage, visualize and continuously monitor a vast amount of data and information from several sources and produce spatial analyses that can support the identification of areas where rehabilitation is essential $[3,18,20,39,40]$.

Ferreira-Lopes et al. [36] presented four main applications of GIS in the field of cultural heritage: as support to create a heritage inventory; to discover patterns of spatial, physical and temporal characteristics to determine future actions in heritage asset management; to develop control and prediction for heritage conservation; and as aid in the definition of strategic plans for natural and/or cultural heritage management. Two more applications can be added to the previous: the monitoring and evaluation of management policies and the dissemination of information. In addition, a wide range of architectural and heritage spatial studies depend on multi-criteria analyses to simplify otherwise complex spatial studies $[39,41]$. These types of analysis, overlaying different characterizing spatial variables, are at the core of geoprocessing GIS procedures.

Petronela et al. [42] reported that, in recent years, this technology was used to develop several important national programmes in many countries (Austria, Cyprus, Czech Republic, Germany, Greece, Iraq, Italy, Japan, Kazakhstan, Malta, Morocco, Russia, Slovak Republic, Spain, Syria, Turkey, United Kingdom, among others) which were focused on collection, processing, verification and centralization of necessary data in the process of managing and preserving immovable cultural heritage (preservation, active or passive restoration, recovery and hoarding).

In this line, Lafreniere et al. [43] advocated the formulation of historical geographic information system (HGIS) or historical spatial data infrastructure (HSDI). According to this author, there is an intention to promote the use of a collaborative consensus model to verify classifications and increase accuracy of manual transcriptions of map data. The harmonization of public collected data with the official historical spatial data in GIS such as the HSDI and PPGIS increases awareness for citizen participation in heritage preservation. 
Examples of GIS models and tools to aid the decision-making process associated with intervention in architectural heritage, in its various applications, can be found at the research level, mainly in the last decade (see Table 2).

The set of applications listed and a recent literature review performed by FerreiraLopes [15] of how GIS has been used in the field of cultural heritage, shows that the application of GIS focuses mainly on the inventory and catalogue of archaeological and architectural heritage, leaving aside their enormous analysis potential.

Table 2. GIS applications in architectural heritage research.

\begin{tabular}{ll}
\hline Field of Research & Source \\
\hline Built heritage and energy efficiency & {$[37,44,45]$} \\
Architectural cultural heritage conservation and management (e.g., castles, religious & {$[4,18-20,36,42,46-49]$} \\
heritage, historical buildings, settlements) & \\
Traditional rural buildings & {$[39,50]$} \\
Contemporary heritage & {$[51]$} \\
City heritage management & {$[13,47,52-55]$} \\
\hline
\end{tabular}

\section{Case Studies from Three European Universities}

\subsection{European Framework}

The growing relevance of GIS is clear and consensual. Based on this assumption, an analysis was performed at an international level (undergraduate (bachelor) and graduate (master and doctoral) programmes) on architecture professionals training on the use of GIS. For this purpose, the most important international classification rankings were considered, and internationally recognized institutions in architecture teaching were selected as references. Ranking organisations address quality of teaching and employability in different ways. The Times Higher Education (THE) World University Rankings uses indicators that show evidence of teaching quality but does not directly address the issue of employability (harder to compare across countries). The Quacquarelli Symonds (QS) World University Rankings uses a survey of employers to determine which universities have the best reputation for producing skilled graduates. Another approach is that of the Academic Ranking of World Universities (Shanghai Rankings), which does not claim to measure either teaching quality or employability, but it focuses mainly on indicators surrounding research excellence (Award indicator). The undertaken analysis revealed that the latter does not differentiate architecture as an academic subject, restricting the analysis to the remaining two indexes.

Both QS and the THE are international world rankings for universities, but they use different methodologies for their computation, either in the number of used indicators or their weights in the final classification. Table 3 presents indicators and weights used in both rankings.

Table 3. Indicators and weights used in QS and THE World University Rankings.

\begin{tabular}{|c|c|c|c|}
\hline \multicolumn{2}{|c|}{$\begin{array}{l}\text { QS-Quacquarelli Symonds } \\
\text { World University Rankings }\end{array}$} & \multicolumn{2}{|l|}{$\begin{array}{l}\text { THE-Times Higher Education } \\
\text { World University Rankings }\end{array}$} \\
\hline Indicators & Weight & Indicators & Weight \\
\hline Academic Reputation & $40 \%$ & Teaching (the learning environment) & $30 \%$ \\
\hline Employer Reputation & $10 \%$ & Research (volume, income and reputation) & $30 \%$ \\
\hline Faculty/Student Ratio & $20 \%$ & Citations (research influence) & $30 \%$ \\
\hline Citations per Faculty & $20 \%$ & International Outlook (staff, students and research) & $7.5 \%$ \\
\hline International Faculty Ratio & $5 \%$ & Industry Income (knowledge transfer) & $2.5 \%$ \\
\hline International Student Ratio & $5 \%$ & Inaustry income (knowieage transier) & $2.5 \%$ \\
\hline
\end{tabular}

Of the top 10 European universities with Architecture classified in each ranking, six appear simultaneously in the QS and THE rankings (see Table 4). 
Of these, the top five in both rankings were considered in an analysis of curricular programmes to assess the offer of compulsory and elective courses in GIS, as well as its use in other courses and in research. The analysis was conducted by collecting the official information available in English on each of the institutional web pages in September 2020 (see Table 5).

From the analysis, it is clear that the majority of the architecture undergraduate and graduate programmes have introduced the use of GIS at different levels. Most of GIS training is performed under elective courses without a previous compulsory GIS course. Several courses present GIS at the undergraduate level, and most have doctorate courses or studios/labs where GIS is used in research. Most of GIS usage in elective courses is applied to urban and territorial planning, and dedicated GIS courses essentially focus on fundamental concepts that underlie the use of a GIS.

Table 4. Rankings of European Universities in Architecture programmes for 2019.

\begin{tabular}{|c|c|c|c|}
\hline \multicolumn{4}{|c|}{ QS-Quacquarelli Symonds World University Rankings } \\
\hline Rank & University & Status & Country \\
\hline 1 & $\begin{array}{l}\text { UCL } \\
\text { (University College London) }\end{array}$ & Public & UK \\
\hline 2 & $\begin{array}{l}\text { Delft University of Technology } \\
\text { (Technische Universiteit Delft) }\end{array}$ & Public & Netherlands \\
\hline 3 & $\begin{array}{l}\text { ETH Zurich-Swiss Federal Institute of Technology in Zurich } \\
\text { (Eidgenössische Technische Hochschule Zürich) }\end{array}$ & Public & Switzerland \\
\hline 4 & University of Cambridge & Public & UK \\
\hline 5 & Manchester School of Architecture & Public & UK \\
\hline 6 & Politecnico di Milano & Public & Italy \\
\hline 7 & $\begin{array}{l}\text { EPFL Federal Institute of Technology in Lausanne (École } \\
\text { Polytechnique Fédérale de Lausanne) }\end{array}$ & Public & Switzerland \\
\hline 8 & The University of Sheffield & Public & UK \\
\hline 9 & $\begin{array}{l}\text { KTH Royal Institute of Technology } \\
\text { (Kungliga Tekniska högskolan) }\end{array}$ & Public & Sweden \\
\hline 10 & $\begin{array}{l}\text { Technical University of Munich } \\
\text { (Technische Universität München) }\end{array}$ & Public & Germany \\
\hline \multicolumn{4}{|c|}{ THE-Times Higher Education Rankings } \\
\hline Rank & University & Status & Country \\
\hline 1 & University of Cambridge & Public & UK \\
\hline 2 & $\begin{array}{l}\text { ETH Zurich—Swiss Federal Institute of Technology in Zurich } \\
\text { (Eidgenössische Technische Hochschule Zürich) }\end{array}$ & Public & Switzerland \\
\hline 3 & $\begin{array}{l}\text { UCL } \\
\text { (University College London) }\end{array}$ & Public & UK \\
\hline 4 & University of Edinburgh & Public & UK \\
\hline 5 & $\begin{array}{l}\text { EPFL Federal Institute of Technology in Lausanne } \\
\text { (École Polytechnique Fédérale de Lausanne) }\end{array}$ & Public & Switzerland \\
\hline 6 & $\begin{array}{l}\text { Technical University of Munich } \\
\text { (Technische Universität München) }\end{array}$ & Public & Germany \\
\hline 7 & $\begin{array}{l}\text { KU Leuven } \\
\text { (Katholieke Universiteit Leuven) }\end{array}$ & Public & Belgium \\
\hline 8 & $\begin{array}{l}\text { Delft University of Technology } \\
\text { (Technische Universiteit Delft) }\end{array}$ & Public & Netherlands \\
\hline 9 & $\begin{array}{l}\text { RWTH Aachen University } \\
\text { (Rheinisch-Westfälische Technische Hochschule Aachen) }\end{array}$ & Public & Germany \\
\hline 10 & University of Glasgow & Public & UK \\
\hline
\end{tabular}


Table 5. Top 5 European Universities and GIS teaching and research.

\begin{tabular}{cl}
\hline University & \multicolumn{1}{c}{ GIS Courses/Use } \\
\hline UCL & Bachelor: Elective GIS course, use of GIS (in compulsory courses) \\
& Master: Use of GIS (in compulsory and elective courses and research) \\
& Doctorate: Use of GIS (lab and research) \\
& Bachelor: Use of GIS (in elective courses) \\
& Master: Use of GIS (in elective courses) \\
& Doctorate: Use of GIS (research) \\
& Bachelor: No course \\
& Master: No course \\
University of Cambridge & Doctorate: Use of GIS \\
& Bachelor: * \\
& Master: Elective GIS course, use of GIS (in compulsory courses). Other masters of \\
& the Faculty of Architecture and the Built Environment with important GIS content: \\
& 1. Geomatics (compulsory and elective courses) \\
& 2. Geographical Information Management and Application (compulsory courses) \\
& Doctorate: Use of GIS (research) \\
& Bachelor: Use of GIS (in compulsory courses) \\
& Master: Use of GIS (in compulsory and elective courses) \\
& Doctorate: * \\
\hline
\end{tabular}

* no reference was found to courses or use of GIS in the information provided in English.

The following subsections present particular aspects of GIS integration in the architecture teaching-learning process and research performed in undergraduate and graduate programmes, with particular focus on regional and urban planning and architectural heritage, at three European universities: University of Seville (Spain), University of Beira Interior (Portugal) and Technical University of Crete (Greece). The section closes with a comparative analysis of GIS teaching approaches adopted at the three universities and those of the five reference universities presented in Table 4.

\subsection{University of Seville}

As a consequence of the Bologna process, the teaching of architecture in Spain has suffered a clear decrease in the number of credits. In the pre-Bologna framework, to be able to exercise the profession, a graduate needed the equivalent to 450 ECTS. Currently, with the homogenization of the studies' structure in bachelor + master, students must complete a $5+1$ year programme, corresponding to a 300 ECTS bachelor degree, usually called in public Spanish universities Fundamentals of Architecture or Studies in Architecture, and a 60 ECTS master's degree in architecture. The master's degree includes a final project exclusively of a professional nature. After approving the enabling professional test, the professional activity can be started, and the new architect may join the different territorial professional associations.

The loss of 90 credits is very relevant because the traditional professional attributions of the architect in Spain were maintained. However, they are wider than in the rest of Europe. Spanish architects can execute and direct without the support of engineers in all levels of urban and territorial planning and calculate structures of building without limitation of extension, height or constructive typology. This loss resulted in a transference of credits to master and doctorate programmes of specialization, more directed to professional applications and research. Among these, it is possible to find the use of GIS in urbanism and heritage. Courses related to graphic expression and construction have only maintained the use of CAD and sparsely BIM.

The bachelor's and master's degrees in architecture recognised in Spain [56] include learning by competences. Among these, and related to urban and territorial planning and heritage, there are essentially five compulsory competences: ability to catalogue the built and urban heritage and plan for its protection; to intervene, preserve, restore and rehabilitate the built heritage; to implement urban standards and ordinances; to develop 
environmental landscape studies and environmental impact corrections; and to draft and manage urban plans at any scale.

In Seville, undergraduate studies comprise 12 modules including Basic sciences; Graphic expression and drawing techniques; History and criticism of architecture and the city; Architectural, urban and intervention in heritage projects; Building, structural and environmental conditioning systems; Urban planning; Land management and landscape planning; Execution projects and construction; and a final degree thesis, which may be oriented to professional or research purpose. The master's degree is composed of a technical module, a project module and the aforementioned final project (enabling professional test).

For more than a decade, the 1998 curriculum of the Higher Technical School of Architecture at Seville University, the last pre-Bologna undergraduate programme, allowed for compulsory, elective and freely configured subjects including "Spatial analysis techniques for the planning study of the territory by means of GIS". In addition, during two editions, a course for the teaching staff was offered. This activity was linked to the first teaching plan at Seville University (2008 and 2009). Both subjects were excluded from the Bologna curriculum for the architecture undergraduate programme. At present, in the subject "Urban planning of protection" teaching is based on GIS philosophy. Collection of urban data is executed with GIS methodology, although students do not work directly on the GIS environment. In this sense, only through the acquisition of optional competences is it possible to have awareness of GIS use. At the University of Seville, GIS is compulsory in the Geography and Territory Management undergraduate programme. However, in the Architecture programme, it depends on the will of teachers to develop student's knowledge of spatial databases. Still, architecture students have contact with other software for representations linked to the architecture project through the Department of Graphic Expression (image editing, 2D/3D CAD and BIM introduction).

In the last fifteen years, the master's degree study programme in architecture and historical heritage dedicates a day to the use of GIS applied in heritage research and intervention, where GIS research is presented and the profitability of using this tool is explained to students. It was also taught in the City and Sustainable Architecture master's degree in 2007-2009.

Considering 3D-model generation of heritage sites, a number of techniques for model generation are available and can be used individually or collaboratively, as several authors indicate [57]. According to them, different heritage typologies (architectural, urban, archaeological and ethnological cultural properties, among others) can demand an integrated approach to overcome the limitations of individual methods and problems with spatial data transference/exchange. This approach has been developed in recent architecture research of the master and doctoral degrees at the University of Seville.

Since 2011, the doctoral programmes are fully inserted in the European Higher Education Area [58,59]. Consequently, collaborations within the Iberian space, namely between the University of Seville and the University of Beira Interior, have been possible and include the promotion of GIS use in architectural heritage research.

An example of doctoral degree study collaborations is the development of an associated digital information model. For instance, the study of water mill traditional architecture of Ribeira do Vascão using GIS [60]; a digital GIS model for the cataloguing of Portuguese Cistercian monasteries and its contemporary rehabilitations [61]; application of GIS in the strictly Sevillian area dealing with the hydraulic mills, as Alcalá de Guadaíra [62], and technical characterization of the medieval churches [63].

Other examples from the field of research are projects that study the development of innovative heritage practices in urban environments that resist the pressure of tourism using GIS, namely "Urban patrimonial characterization and tourist cultural model in medium-sized cities. Potentials and challenges for internationalization: Inner Betica" (Figure 1) [50]. 


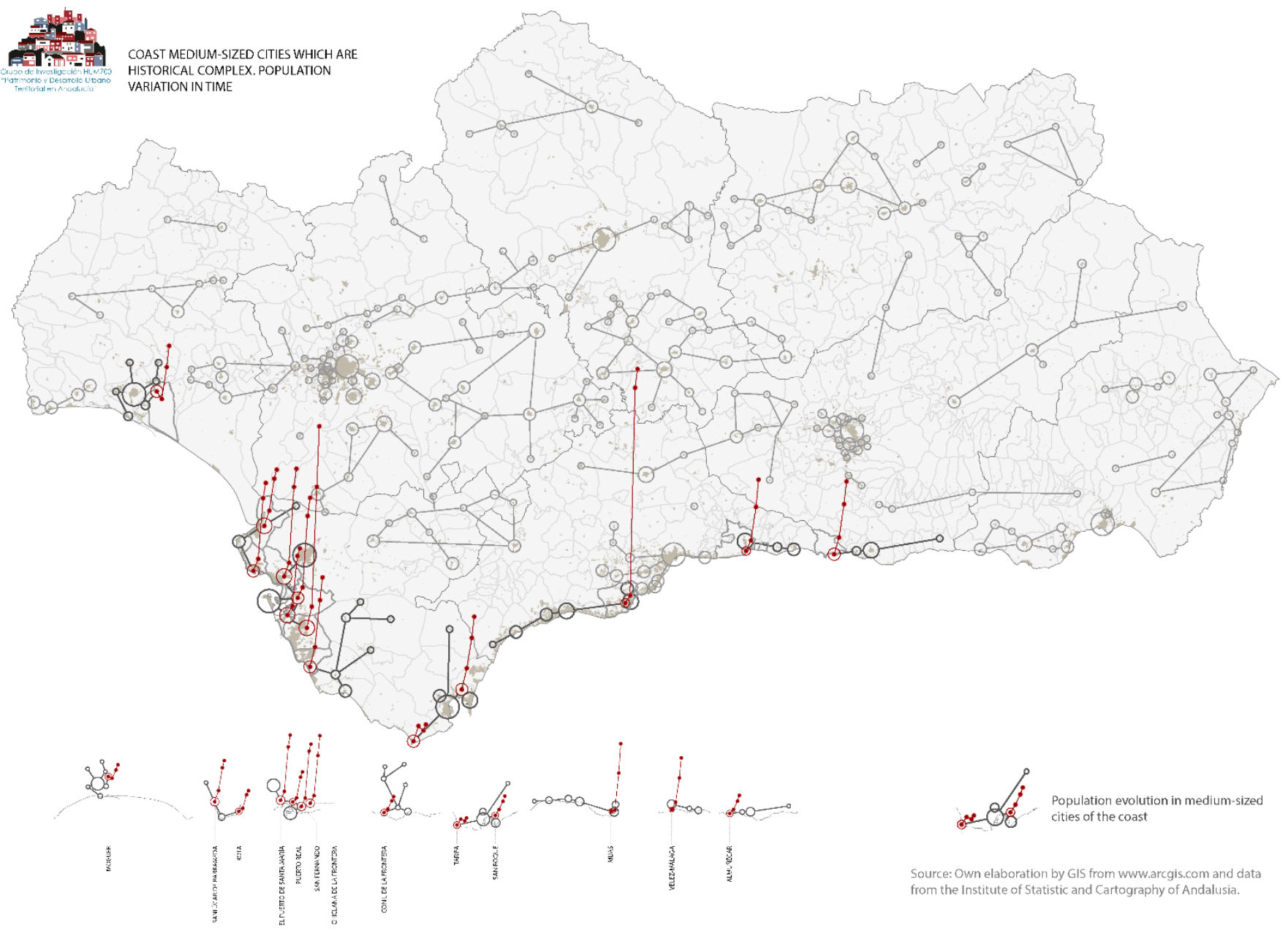

Figure 1. The coast effect on the growth of medium-sized cities of Andalusia (retrieved from [50]).

Mention should also be made of the role of GIS in the progressive definition of urban renewal analysis [55] and cultural landscape management models, allowing the configuration of relevant information of more than 100,000 cultural properties of Andalusia (Spain) [64].

\subsection{University of Beira Interior}

The Bologna Declaration introduced changes in Portuguese universities that required a reorganization of learning programmes in architecture schools. The University of Beira Interior (UBI) was one of these universities [65]. The integrated master in architecture at the UBI is a 5-year programme that combines undergraduate (bachelor) and postgraduate (master) studies [12,34].

In the first 3 years, students can obtain a bachelor degree in basic architecture skills after the completion of six semesters (180 ECTS). In the final 2 years, students may obtain a master degree in architecture, comprising three semesters of curricular units (90 ECTS) and one semester entirely dedicated to a dissertation or project (30 ECTS) that can be practical (architectural project) or theoretical (dissertation).

At the UBI's master degree in architecture, the basis of architectural knowledge is achieved not only by technical curricular units but also by a history and a theoretical course intertwined with the project curricular units $[12,66]$. The interdisciplinarity and interrelation, which links both research and education, are the basis for the production of knowledge at the UBI Department of Civil Engineering and Architecture [12,13,34,67]. Among the different research themes, particular attention is devoted to building heritage in Portugal and its connection with engineering sciences such as thermal comfort, acoustics, 
daylighting and more recently with GIS as a way of spatial analysis to support project decision.

In 2015, this degree had a curricular design revision and consequently the allocation of more time to the teaching of History of Architecture and the need to assign a specific syllabus to the Portuguese Architecture and City History. With this course revision, it was possible to merge interests within the scope of GIS and History of Portuguese Architecture as well as to introduce the use of a GIS-based problem solving in the dissertations to achieve the master degree in architecture [13].

Considering the eight traditional integrated master degrees in architecture taught at Portuguese public universities (5-year programmes), the one at the UBI is the only one with a compulsory GIS course [12].

UBI architecture students are introduced to aspects related to geographical information in the second semester of the third year. In this introductory-level course, they are provided with theoretical and practical knowledge and skills required to be fluent in the most common geographic data types used in GIS, spatial analysis and mapping representation.

To introduce UBI students to GIS and to its applicability in the study of architectural solutions, scholars have adopted a student-centred pedagogy supported by project-based learning (PBL) [68]. This type of learning is in line with what Drennon [1], Schulze et al. [7], Muntazar et al. [3], Garcia-Almirall [69] and Bearman et al. [70] defined as fundamental points for a good GIS education, including GIS teaching in architecture. In practical terms, scholars structure and plan the activities, and students are expected to raise, discuss, implement and evaluate problems with applications in the real world, considering their different perspectives and backgrounds.

This teaching methodology has been tested by UBI scholars in previous editions of the master's degrees in architecture and in geographic information systems. Teaching experience led to dividing the GIS course into three distinct blocks with the common distinction between theory and practice: (a) theoretical classes, (b) practical classes (introduction to tool use and practical exercises) and (c) real spatial problem resolution through the PBL approach [12], involving the use of maps, aerial photography, online data and information collected in situ; creation of a database; use of spatial analysis tools; and preparation of thematic maps.

GIS is not only taught as a geographical reference basis for surveys and inventories but also to analyse spatial data and to publicize Portuguese heritage, being the key element that intertwines all the information. The disciplinary interconnection of third-year students' research on Portuguese religious built heritage and traditional tiles ("azulejos" in Portuguese) at Covilhã (Portugal), implementing a GIS-based inventory and analysis, are examples of real spatial problems developed by students.

This approach started in the 2017/2018 academic year [12] and evolved in 2019 to a partnership with Covilhã Municipality. Examples of the solutions obtained by students are presented in Figures 2-4. 

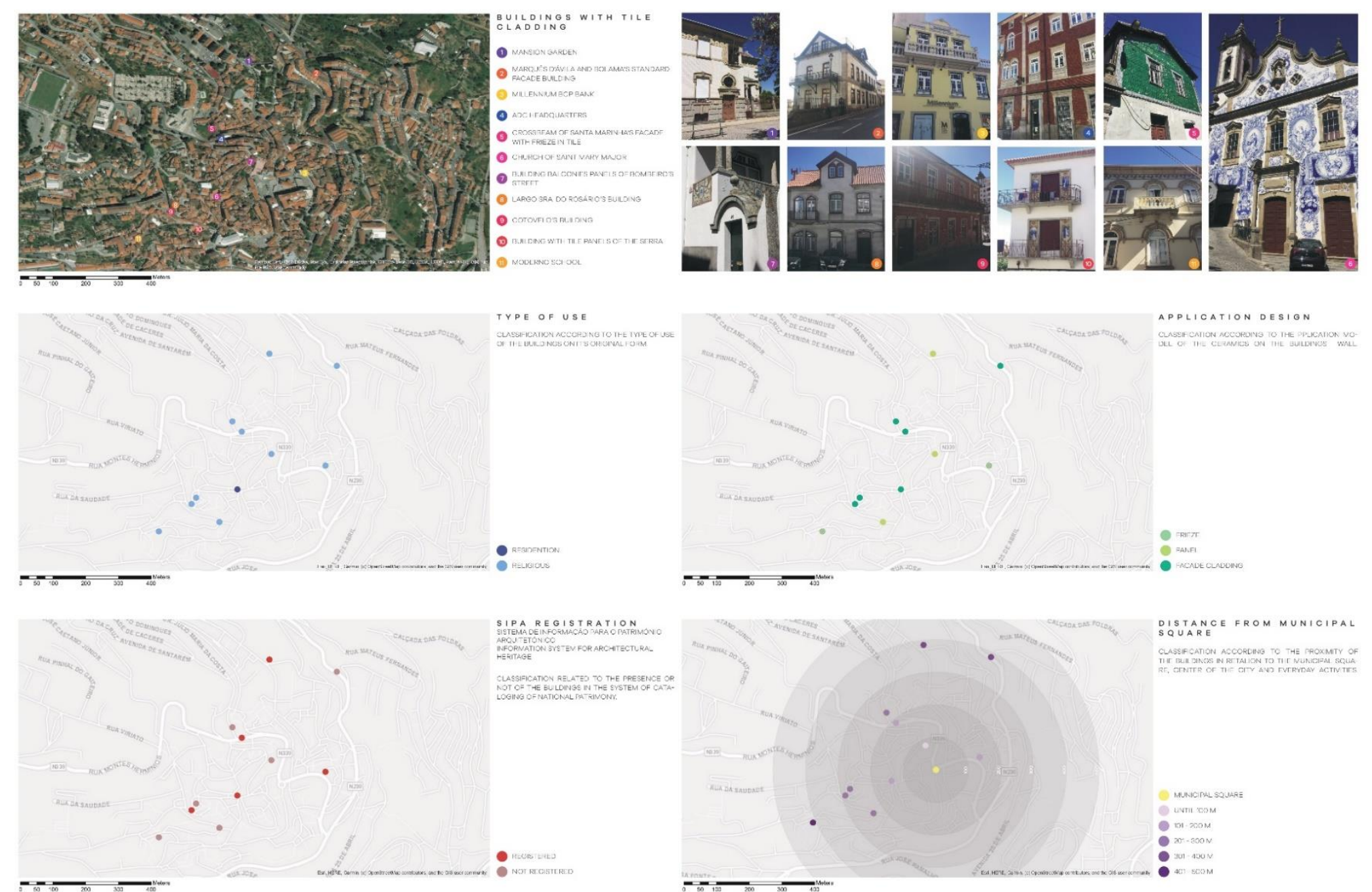

IJIII INUENT ORY OF TILE HER ITAOE

Figure 2. Example of a GIS layout performed by students: buildings with traditional tile facades (work developed in partnership with History of Portuguese Architecture I course). 
GIS APPLIED TO THE ANALYSIS DF RELIGIGUS HERITAGE GF CDVILHÃ RELIEIOUS HERITAGE MAP IN THE PARISHES IF COVILHÄ AND CANHOSD 1. PROTECTION'S ZONE OF HISTORICAL BUILDINGS

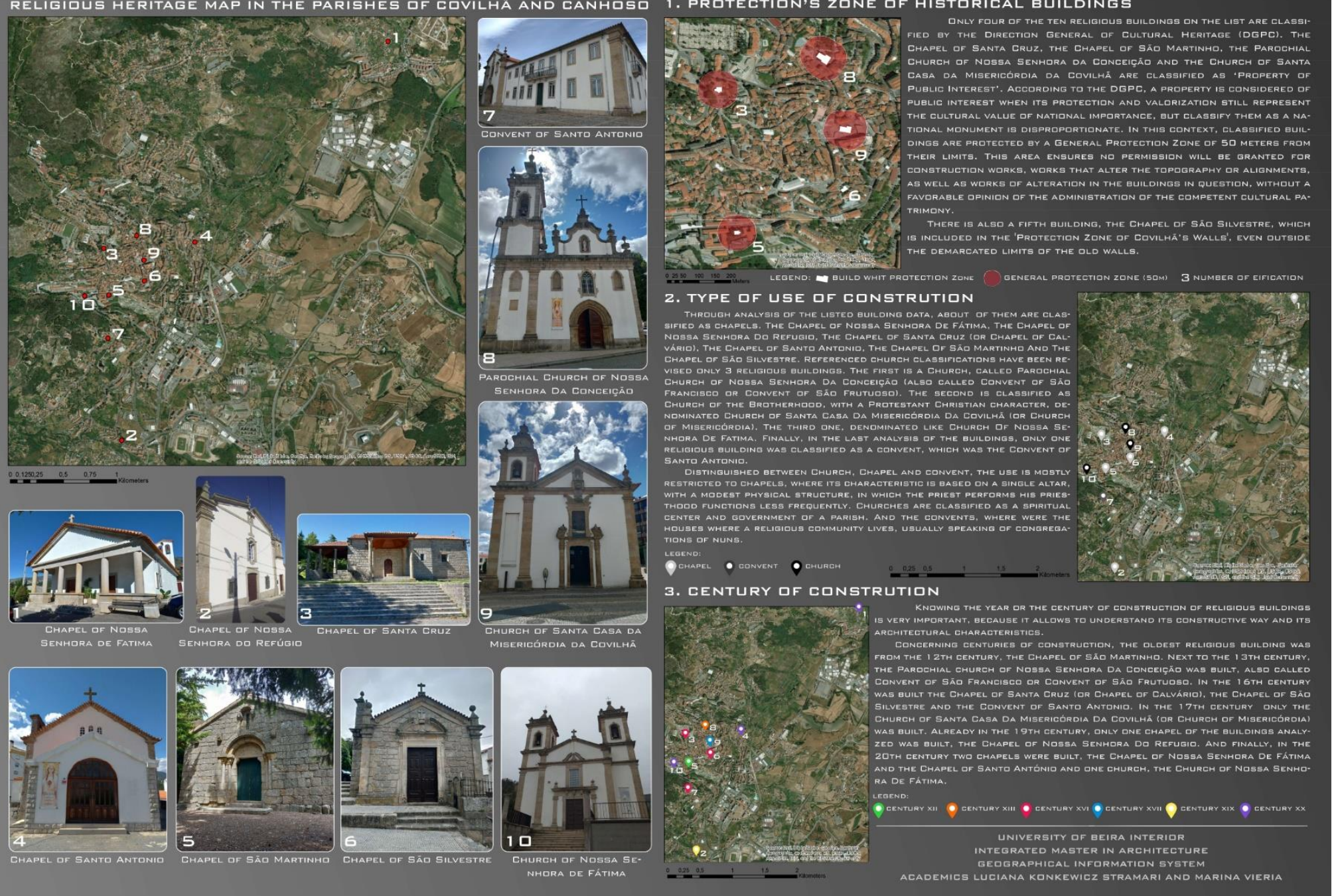

Figure 3. Example of a GIS layout performed by students: religious heritage (work developed in partnership with History of Portuguese Architecture I course). 


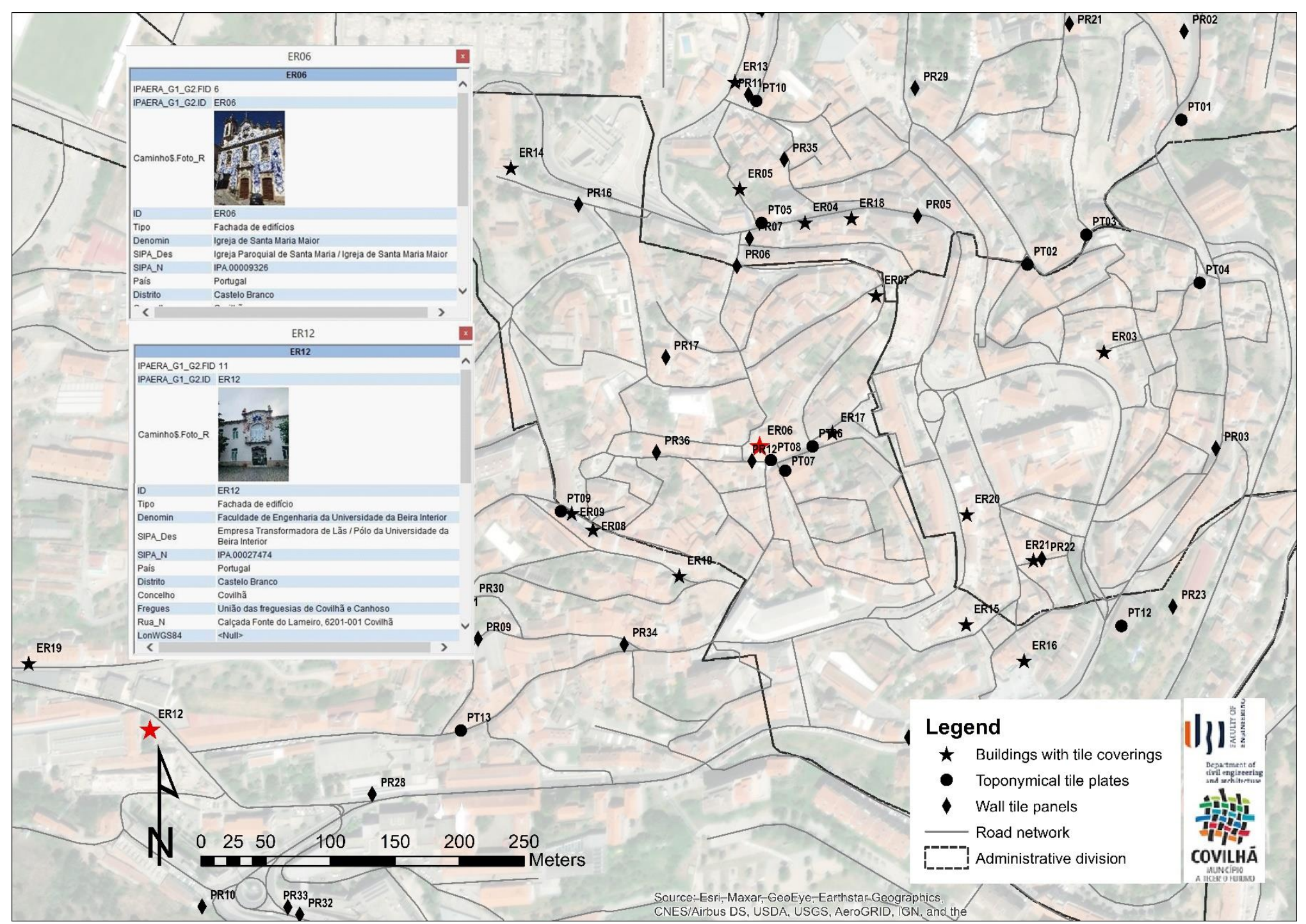

Figure 4. Spatial distribution of glazed tile works considered in a GIS-tool proof of concept developed in partnership with Covilhã Municipality (adapted from [51]). 


\subsection{Technical University of Crete}

The Technical University of Crete (TUC) School of Architecture was established in 2004. The School is divided into four sectors: Architectural Planning, History and Theory, Construction Technology and Urban and Regional Planning. Its foundation followed the rules of the Ministry of Education dictating that architecture students should have a complete education in architecture with skills regarding all scales of planning.

In this framework, urban and regional planning are taught at least in 6 of the 10 semesters of architectural studies. During the first six semesters, students are introduced to the basic fields of planning (180 ECTS). In the next two semesters, students are trained on more complex projects (60 ECTS), and in the ninth semester (30 ECTS), they proceed with their research dissertation which requires a theoretical approach of a planning subject. During the same semester, they specialize in a field of architecture of their interest following elective courses that focus on specific architectural fields such as Urban Planning, Urban Design or Construction Materials. Finally, the 10th semester is dedicated to the Dissertation or Project (30 ECTS) which should be practical.

The School of Architecture of the TUC has followed other architectural schools of Greek universities and has implemented the use of GIS in its studies. In the Architectural Schools of both the Aristotle University of Thessaloniki and the University of Thessaly, GIS is taught as an elective course; however, in the corresponding Planning and Regional Development Departments of Thessaloniki and Volos, GIS is fully integrated in the undergraduate programme of studies. In the School of Architecture of the National Technical University of Athens (NTUA), GIS is currently taught as a compulsory-elective course in the Architecture and Spatial Design post-graduate programme.

In 2018, the compulsory-elective course Introduction to Geographic Information Systems in Large-scale Planning was introduced by the urban and regional planning sector at the TUC School of Architecture. This GIS course is taught in the seventh semester of the undergraduate programme and is considered important to support planning and design at an urban and regional scale. The main target of the course is not only to introduce the basic concepts and methods regarding GIS tools but also to train students on how to apply specific data analysis procedures and to use the available open data and web-GIS platforms to support the urban planning process.

Typical distinction between theory and practice was also adopted. During the first lessons, scholars focus on theory presentation, involving (a) the multi-disciplinary role of GIS in current science and research and (b) the way GIS can be used to handle spatial information and to solve problems by identifying spatial relationships. The role of highresolution geodata in management issues related to architecture and urban planning, such as land-use conflicts, environmental planning, smart cities, cultural heritage and tourism development, is analysed. Students are presented with examples of how GIS has been used to make informed decisions on real-world spatial problems.

In the second stage, classes focus on GIS practice. Specific geoprocessing procedures and tools are taught, while the methodology for constructing thematic maps is presented. Students apply these tools and methods to analyse a case study area in the region of Athens. During classes, students make use of a wide range of spatial data (regarding land-use distribution, transportation networks, green urban spaces, environmental areas, etc.) and analyse the form and structure of specific areas. Geoprocessing tools are also used to analyse spatial relationships between residential areas, educational facilities and public buildings, including cultural heritage monuments, archaeological sites, etc. Moreover, the socio-spatial structure of the city is analysed by linking the spatial data to socioeconomic, demographic and housing quality data.

Following the positive response of students to this course, further steps have been taken. Aiming towards better integration of GIS in architectural studies, a second course targeted to more advanced GIS users was implemented in 2020. This course is entitled Current Methods in the Analysis of City Space Using GIS Technologies and aims to directly address the issues of urban planning for sustainable development in the European context. 
A comparative analysis of cities, taking advantage of 3D information, is applied in order to measure and evaluate the compactness of urban areas and address the problem of urban sprawl. The analysis of urban form is linked to quality of life indicators, accessibility to urban green areas, evaluating policies and supporting planning decisions.

An example of the solutions obtained by students is presented in Figure 5. This study aimed to identify the accessibility of an urban area, estimated at an urban block level, by combining data related to geometric distance from metro stations, public buildings, and commercial facilities, using a weighted expression based on map algebra.
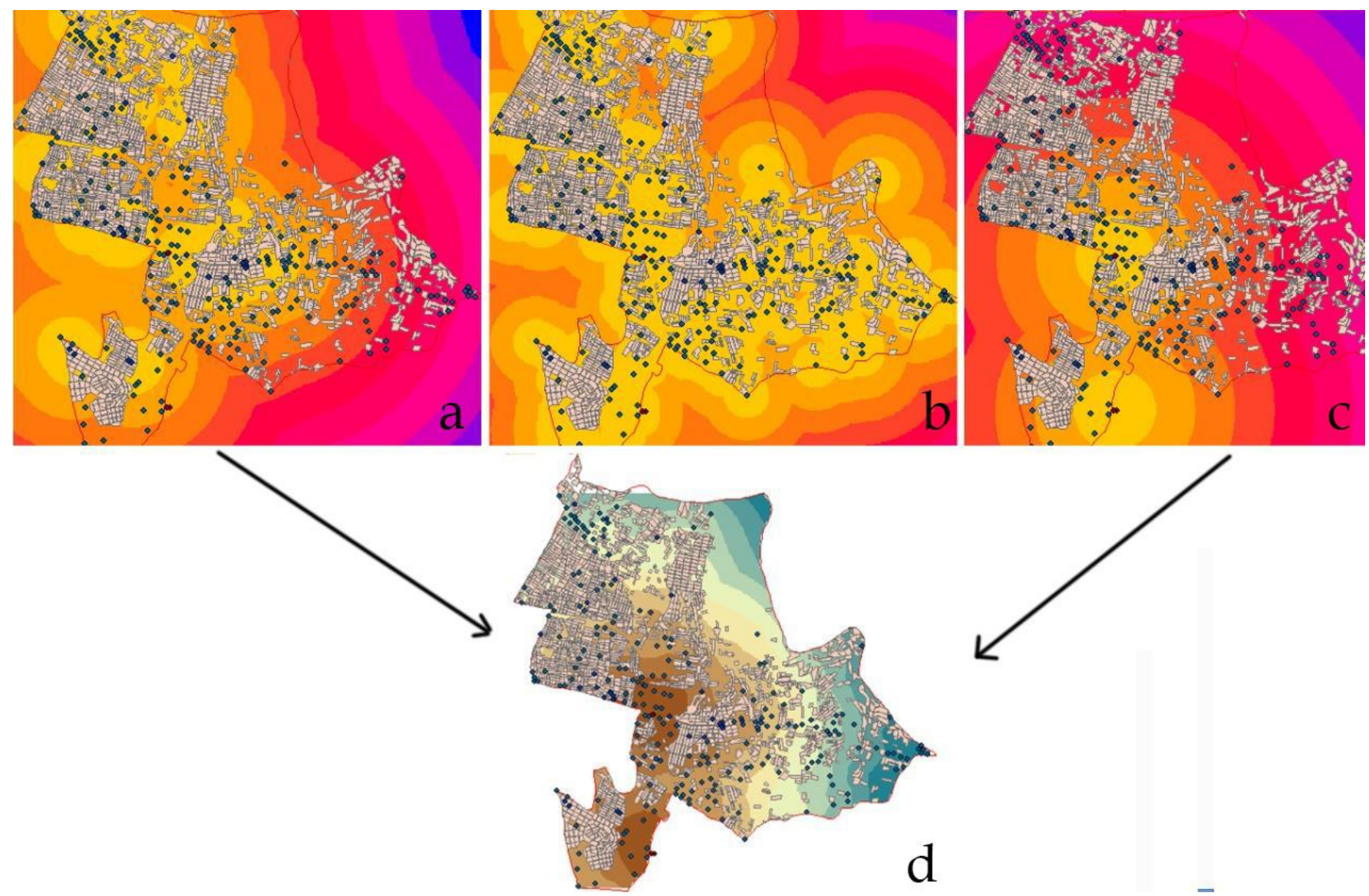

Figure 5. Estimation of combined accessibility to different points of interest within an urban sector of Athens using map algebra: (a) Distance from commercial facilities, (b) Distance from public buildings, (c) Distance from metro stations, (d) Combined accessibility.

\subsection{Findings}

Table 6 presents a summary of the GIS teaching and research of the three European Universities described in Sections 5.2-5.4.

The summary presented shows that two of the three universities (Beira Interior and Crete) currently offer a compulsory and compulsory-elective GIS course at the undergraduate level. However, it is still important to notice that the University of Seville had incorporated, in previous pre-Bologna undergraduate programmes, compulsory and elective GIS-related courses.

At the postgraduate level (master and doctorate) all universities show the use of GIS in research, revealing the current tendency to explore GIS potential for cadastre and spatial analysis, in particular in urban and regional planning and architectural heritage.

Compared to the top five European universities offering architecture programmes (Table 5), there is a greater recognition of the need for GIS training at the undergraduate level at the three analysed universities. This shows an advance in the acquisition of digital 
skills and the modernization of the architecture profession contributing to an improvement of students' knowledge on the use of GIS in postgraduate studies.

Table 6. GIS teaching and research in Seville, Beira Interior and Crete Universities/Technical University.

\begin{tabular}{cl}
\hline \multicolumn{1}{c}{ University } & \multicolumn{1}{c}{ GIS Courses/Use } \\
\hline University of Seville & Bachelor: No course (GIS-related compulsory and elective courses in \\
& pre-Bologna programme-use of GIS) \\
& Master: Use of GIS (research), day dedicated to the use of GIS \\
& Doctorate: Use of GIS (research) \\
University of Beira Interior & Bachelor: Compulsory GIS course \\
& Master: Use of GIS (research) \\
& Doctorate: - \\
Technical University of Crete & Bachelor: Compulsory-elective GIS course \\
& Master: - \\
& Doctorate: - \\
\hline
\end{tabular}

The relevance of GIS in postgraduate European architecture programmes is consensual, revealing an extended use in research work.

\section{Conclusions}

Architectural curricula tend to prioritize the field of construction, narrowing the possibilities to renew skills. Curricular units on territory and heritage are practically testimonial, generally of analytical nature. Undergraduate and postgraduate degrees are generally dedicated to strictly vocational training and these topics are viewed in a purely academic and formalistic way. Relevant topics such as heritage or sustainability are transferred to specialization programmes, working in a dimension closer to reality.

The use of digital technologies has expanded the possibilities of generating even more interdisciplinary projects. Architecture curricula have gradually introduced constructionrelated digital technologies such as computer-aided design, virtual reality, augmented reality or building information modelling. The availability of spatial ICT, tools and techniques with more functional and user-friendly interfaces makes it possible to identify and visualize previously invisible evidence, synthesise and map temporal information and combine data from various sources to generate new data and hypotheses.

Findings from the international classification rankings analysis show that GIS integration into the architecture curricula at a European level is neither homogeneous nor consensual and significant differences are found in GIS training. This reality contrasts with its increasing application to research and professional practice.

In fact, some architects still do not use digital spatial analysis tools mainly because of their lack of skills concerning analysis and territorial planning. This leads to a loss of competitiveness in the labour market, despite being present in the field of architecture research. A better integration of GIS in architectural design, heritage and urban and regional planning courses is crucial. Most architecture programmes already use GIS technology but still rely on the student's willingness to learn GIS fundaments.

Literature review highlights the existence of many applications in urban, regional and architectural heritage cadastre. However, there is a clear need for educational training to take advantage of the full potential of information analysis and decision support that GIS allows.

Students should be able to explore the use of GIS tools from earlier years in order to analyse case-study areas and to better understand how GIS technology is able to support the process of planning and management. The three universities concerned are committed to the undergraduate training of GIS in architecture as a way to prepare and integrate students in current and future demands in research and the job market.

Future developments must include earlier and wider teaching of GIS and the integration of other ICT, tools and techniques in postgraduate studies and research projects 
(such as geomatics, 3D GIS, BIM, virtual reality, mixed reality, open-source tools and web applications). This implies a proper transfer of knowledge to the teaching community, as it is common practice in other fields of knowledge. Students will thus benefit from a comprehensive training to become professionals of the future with a more innovative, flexible and competitive profile.

Author Contributions: Conceptualization, B.S., J.G., A.M.M., M.T.P.-C., E.M.-A., D.D. and A.L.; methodology, B.S. and J.G.; investigation, B.S., J.G., A.M.M., M.T.P.-C., E.M.-A., D.D. and A.L.; writing-original draft preparation, B.S. and J.G.; writing—review and editing, B.S., J.G., A.M.M., M.T.P.-C., E.M.-A., D.D., A.L. and P.G.A.; supervision, B.S. and J.G. All authors have read and agreed to the published version of the manuscript.

Funding: The APC is partially supported by Portuguese national funds by FCT (Foundation for Science and Technology), I.P., within the GEOBIOTEC—Project UIDB/04035/2020.

Acknowledgments: The authors acknowledge the University of Beira Interior, Lab2PT-Landscapes, Heritage and Territory laboratory (AUR/04509), CIDEHUS-Interdisciplinary Centre for History, Cultures and Societies (HIS/00057), CITTA—-Research Centre for Territory, Transports and Environment (Multi/04427), CERIS-Civil Engineering Research and Innovation for Sustainability (ECI/04625) and GEOBIOTEC-GeoBioSciences, GeoTechnologies and GeoEngineering (GEO/04035) for supporting the performed study.

Conflicts of Interest: The authors declare no conflict of interest.

\section{References}

1. Drennon, C. Teaching Geographic Information Systems in a Problem- Based Learning Environment. J. Geogr. High. Educ. 2005, 29, 385-402. [CrossRef]

2. Paradis, T.; Treml, M.; Manone, M. Geodesign Meets Curriculum Design: Integrating Geodesign Approaches into Undergraduate Programs. J. Urban. Int. Res. Placemaking Urban Sustain. 2013. [CrossRef]

3. Monsur, M.; Zakiul, I. GIS for Architects: Exploring the Potentials of Incorporating GIS in Architecture Curriculum. ARCC Conf. Repos. 2014. [CrossRef]

4. Puerto, F.P.; Fornos, R.A.; Román, M.C.; Dorado, J.A.; Lopes, P.F. Using BIM and GIS to Research and Teach Architecture. In Architectural Draughtsmanship; Perea, E.C., Valiente, E.E., Eds.; Springer: Berlin/Heidelberg, Germany, 2018. [CrossRef]

5. Brunetaud, X.; De Luca, L.; Janvier-Badosa, S.; Beck, K.; Al-Mukhtar, M. Application of Digital Techniques in Monument Preservation. Eur. J. Environ. Civ. Eng. 2012, 16, 543-556. [CrossRef]

6. Freire, G.J.d.M. Reinserimento Degli Spazi Urbani di Insediamenti Precari (Favelas) Mediante il GIS. Disegnarecon 2013, 6, 71-80. [CrossRef]

7. Schulze, U.; Kanwischer, D.; Reudenbach, C. Essential Competences for GIS Learning in Higher Education: A Synthesis of International Curricular Documents in the GIS\&T Domain. J. Geogr. High. Educ. 2013. [CrossRef]

8. Sinton, D.S. Roles for GIS within Higher Education. J. Geogr. High. Educ. 2009. [CrossRef]

9. Kim, M.; Bednarz, R. Development of Critical Spatial Thinking through GIS Learning. J. Geogr. High. Educ. 2013. [CrossRef]

10. Hwang, S. Placing GIS in Sustainability Education. J. Geogr. High. Educ. 2013. [CrossRef]

11. Summerby-Murray, R. Analysing Heritage Landscapes with Historical GIS: Contributions from Problem-Based Inquiry and Constructivist Pedagogy. J. Geogr. High. Educ. 2001, 25, 37-52. [CrossRef]

12. Santos, B.; Martins, A.; Campos, I.; Gonçalves, J.; Almeida, P. When Past and Future Meet in Architecture Teaching: Heritage and GIS. In Proceedings of the ICERI 2018-11th annual International Conference of Education, Seville, Spain, 12-14 November 2018; pp. 902-910.

13. Martins, A.; Gonçalves, J.; Santos, B.; Marques, S. Learning from the Historic City: Architectural Heritage Rehabilitation and GIS, The URS-VISEU NOVO (Portugal) Legacy. In Proceedings of the INTED 2019-13th International Technology Education and Development Conference, Valencia, Spain, 11-13 March 2019; pp. 8993-9001.

14. Kara, L. A Critical Look at the Digital Technologies in Architectural Education: When, Where, and How? Procedia Soc. Behav. Sci. 2015, 176, 526-530. [CrossRef]

15. Ferreira-Lopes, P. Achieving the State of Research Pertaining to GIS Applications for Cultural Heritage by a Systematic Literature Review. Int. Arch. Photogramm. Remote Sens. Spat. Inf. Sci. 2018, 42, 249-252. [CrossRef]

16. Blišt'an, P.; Kovanič, L'.; Kovaničová, M. The Importance of Geographic Information Systems Education at Universities in the Process of Building a European Knowledge-Based Society. Procedia Soc. Behav. Sci. 2015, 191, 2458-2462. [CrossRef]

17. Wang, H.; Pan, Y.; Luo, X. Integration of BIM and GIS in Sustainable Built Environment: A Review and Bibliometric Analysis. Autom. Constr. 2019, 103, 41-52. [CrossRef] 
18. Karsli, F.; Ayhan, E.; Tunc, E. Building 3D Photo-Texture Model Integrated with GIS for Architectural Heritage Conservation. In Proceedings of the XIXth International Symposium, CIPA 2003: New perspectives to save cultural, Antalya, Turkey, 30 September-6 October 2003; pp. 144-147.

19. Toz, G.; Duran, Z. Documentation and Analysis of Cultural Heritage by Photogrametric Methods and GIS: A Case Study. Int. Arch. Photogramm. Remote Sens. Spat. Inf. Sci. 2004, XXXV, 1-5.

20. Droj, G. Cultural Heritage Conservation by GIS. In GISOPEN; Nyugat-Magyarországi Egyetem, Geoinformatikai Kar: Székesfehérvár, Hungary, 2010.

21. Seker, D.Z.; Alkan, M.; Kutoglu, H.; Akcin, H.; Kahya, Y. Development of a GIS Based Information and Management System for Cultural Heritage Site; Case Study of Safranbolu. In Proceedings of the FIG-Fédération Internationale des Géomètres Congress, Sydney, Australia, 11-16 April 2010. No. 1-10.

22. Portman, M.E.; Natapov, A.; Fisher-Gewirtzman, D. To go where no man has gone before: Virtual Reality in Architecture, Landscape Architecture and Environmental Planning. Comput. Environ. Urban Syst. 2015, 54, 376-384. [CrossRef]

23. Pedro, J.; Silva, C.; Pinheiro, M.D. Integrating GIS Spatial Dimension into BREEAM Communities Sustainability Assessment to Support Urban Planning Policies, Lisbon Case Study. Land Use Policy 2019, 83, 424-434. [CrossRef]

24. Dekolo, S.O.; Oduwaye, L. GIS in Urban and Regional Planning. In Proceedings of the Nigerian Institute of Town Planners CPD Workshop, Lagos, Nigeria, 1 January 2005. [CrossRef]

25. Faludi, A. A Reader in Planning Theory, 1st ed.; Pergamon Press: Oxford, NY, USA, 1973.

26. European Parliament and Council. I Directive 2007/2/EC of the European Parliament and of the Council of 14 March 2007 Establishing an Infrastructure for Spatial Information in the European Community (INSPIRE). Off. J. Eur. Union 2007, 50, 14.

27. Stauskis, G. Development of Methods and Practices of Virtual Reality as a Tool for Participatory Urban Planning: A Case Study of Vilnius City as an example for improving Environmental, Social and Energy Sustainability. Energy. Sustain. Soc. 2014. [CrossRef]

28. LeGates, R.T. Competency-Based UK Urban Spatial Planning Education. J. Educ. Built Environ. 2009, 4, 55-73. [CrossRef]

29. Martín, M. Sobre El necesario vínculo entre el Patrimonio y La Sociedad. Reflexiones críticas sobre la interpretación del Patrimonio. Estud. Património 2001, 1, 25-37.

30. Ripp, M.; Rodwell, D. The Geography of Urban Heritage. Hist. Environ. Policy Pract. 2015. [CrossRef]

31. Martins, A.; Carlos, J. The Re-Use(s) of a Cistercian Monastery in Lisbon. ACEE J. Archit. Civ. Eng. Environ. 2013, 6, 45-60.

32. Martins, A.; Pérez-Cano, M.T.; Mosquera-Adell, E. Monastic Buildings: A review about new uses on former Monasteries. The Portuguese Cistercian case. IOP Conf. Ser. Mater. Sci. Eng. 2019, 471, 082037. [CrossRef]

33. Torsello, B.P. Proyecto, conservación, innovación. Loggia 1999, 8, 10-17. [CrossRef]

34. Martins, A.; Carlos, J.; Nepomuceno, M. Built Heritage Research and Education. In Proceedings of the EDULEARN 18-9th International Conference on Education and New Learning Technologies, Palma de Mallorca, Spain, 3-5 July 2017; pp. 10268-10277. [CrossRef]

35. Mine, T.Z. Adaptive Re-Use of Monuments: Restoring Religious Buildings with Different Uses. J. Cult. Herit. 2013, 14, S14-S19. [CrossRef]

36. Ferreira-Lopes, P.; Pinto-Puerto, F. GIS and Graph Models for Social, Temporal and Spatial Digital Analysis in Heritage: The Case-Study of Ancient Kingdom of Seville Late Gothic Production. Digit. Appl. Archaeol. Cult. Herit. 2018. [CrossRef]

37. Caputo, P.; Pasetti, G. GIS Tools towards a renovation of the Building Heritage. Energy Procedia 2017, 133, 435-443. [CrossRef]

38. Saygi, G.; Remondino, F. Management of Architectural Heritage Information in BIM and GIS: State-of-the-Art and Future Perspectives. Int. J. Herit. Digit. Era 2013, 2, 695-713. [CrossRef]

39. Cano, M.; Garzón, E.; Sánchez-Soto, P.J. Historic Preservation, GIS, \& Rural Development: The Case of Almería Province, Spain. Appl. Geogr. 2013, 42, 34-47. [CrossRef]

40. Navas-Carrillo, D.; Hidalgo, B.D.E.; Navarro-De Pablos, F.J.; Cano, M.T.P. The Urban Heritage Characterization Using 3D Geographic Information Systems. The System of Medium-Sized Cities in Andalusia. Int. Arch. Photogramm. Remote Sens. Spat. Inf. Sci. ISPRS Arch. 2018, 42, 127-134. [CrossRef]

41. Nogueira, T.D.; Laboratorio di Geoprocessing. Disegno e Gestione dell' Occupazione Territoriale com il Supporto del Telerilevamento e dei Sistemi Informativi Geografici-Bassi Costi e Grandi Benefici in Brasile. Disegnarecon 2013, 6, 49-60. [CrossRef]

42. Petronela, S.; Adrian, U.; Ion, S. Heritage Management using GIS. In Proceedings of the 16th International Multidisciplinary Scientific GeoConference SGEM, Albena, Bulgaria, 30 June-6 July 2016; pp. 263-270.

43. Lafreniere, D.; Weidner, L.; Trepal, D.; Scarlett, S.F.; Arnold, J.; Pastel, R.; Williams, R. Public Participatory Historical GIS. Hist. Methods J. Quant. Interdiscip. Hist. 2019, 52, 132-149. [CrossRef]

44. Fabbri, K.; Zuppiroli, M.; Ambrogio, K. Heritage Buildings and Energy Performance: Mapping with GIS Tools. Energy Build. 2012, 48, 137-145. [CrossRef]

45. Buffat, R.; Schmid, L.; Heeren, N.; Froemelt, A.; Raubal, M.; Hellweg, S. GIS-Based Decision Support System for Building Retrofit. Energy Procedia 2017, 122, 403-408. [CrossRef]

46. Oppio, A.; Bottero, M.; Ferretti, V.; Fratesi, U.; Ponzini, D.; Pracchi, V. Giving Space to Multicriteria Analysis for Complex Cultural Heritage Systems: The Case of the Castles in Valle D'Aosta Region, Italy. J. Cult. Herit. 2015, 16, 779-789. [CrossRef] 
47. Husseini, B.; Bali, Z. Documentation, Using GIS Techniques in Conservation of a World Heritage Site, a Case Study of "the Old City of Jerusalem". In Proceedings of the International Archives Photogrammetry Remote Sensing Spatial Information ScienceISPRS Archives 25th International CIPA Symposium, Taipei, Taiwan, 31 August-4 September 2015; Volume 40, pp. 229-234. [CrossRef]

48. Lianos, N.; Stamnas, A. A Recording and Documentation System of Building Stock: The Case of Pentalofos Settlement in Kozani (Greece). In Proceedings of the 8th International Congress in Archaeology, Computer Graphics, Cultural Heritage and Innovation-ARQUEOLÓGICA 2.0, Valencia, Spain, 5-7 September 2016; pp. 89-94. [CrossRef]

49. Santos, B.; Gonçalves, J.; Martins, A.; Almeida, P. Safeguarding Portuguese Traditional Glazed Tile Cultural Heritage with GIS. IOP Conf. Ser. Mater. Sci. Eng. 2020, 949, 012071. [CrossRef]

50. Pérez-Cano, M.T.; Prieto, J.; Adell, E.; Jiménez, C.; Naranjo, M.; Fuentes, D. Caracterizacion Urbano Patrimonial y Modelo Turistico Cultural en Ciudades Medias. Potencialidades y Retos para su Internacionalizacion: Betica Interior. Available online: http:/ /institucional.us.es/innerbaetica/index.html (accessed on 11 January 2021).

51. Rodríguez-Lora, J. La Protección Del Patrimonio Contemporáneo. Arquitectura En Torno Al Movimiento Moderno En Sevilla. Una Revisión Urbano-Patrimonial Tres Décadas Después. Master's Thesis, Universidad de Sevilla, Sevilla, Spain, 2018.

52. Chatzigrigoriou, P.; Mavrikas, E. Saving Historic Buildings with Multi-Criteria GIS Tool: The Case of Hermoupolis-Cyclades. In Proceedings of the 2013 Digital Heritage International Congress (DigitalHeritage), Marseille, France, 28 October-1 November 2013; Volume 2, pp. 53-59. [CrossRef]

53. Bushmakina, Y.V.; Balyberdina, P.A.; Dmitrieva, M.K.; Gogoleva, M.V. The Use of GIS for Studying Cultural Heritage and Historical Urban Landscape: The Case of Perm and Usolie (Russia). Ge-Conservación 2017, 1, 264-271. [CrossRef]

54. Almeida, V. Valores Urbanos e Património na Definição de Princípios de Intervenção: O Centro Histórico de Viseu. Mestrado em Reabilitação Urbana. Ph.D. Thesis, Universidade de Coimbra, Coimbra, Portugal, 2017.

55. Pérez-Cano, M.T. Medium-Sized Cities of Inner Baetica. In Catálogo exposición IMPACT-Ciudades Medias de la Bética Interior; PérezCano, M.T., Ed.; HUM700-Patrimonio y Desarrollo Urbano Territorial en Andalucía: Sevilla, Spain, 2019; ISBN 978-84-09-17265-8.

56. Ministerio de Educación. Disposición 12269 Del BOE Núm. 185; 2010; Available online: https://www.boe.es/boe/dias/2010/07/ 31/pdfs/BOE-A-2010-12269.pdf (accessed on 11 January 2021).

57. Albourae, A.T.; Armenakis, C.; Kyan, M. Architectural Heritage Visualization using Interactive Technologies. Int. Arch. Photogramm. Remote Sens. Spat. Inf. Sci. 2017, 42, 7-13. [CrossRef]

58. Martins, A.; Girão, J.; Rosado, A. La Internacionalización de la Investigación en Patrimonio. Resultados y Experiencias. In Proceedings of the XV Foro Internacional Sobre la Evaluación de la Calidad de la Investigación y de la Educación SuperiorFECIES, Granada, Spain, 10-12 May 2018.

59. Martins, A.; Mosquera-Adell, E.; Pérez-Cano, M.T.; Royo-Naranjo, L.; Aladro-Prieto, J. Built Heritage Research and Education: Iberian Experience. In Proceedings of the ICERI2018-11th Annual International Conference of Education, Research and Innovation Proc., Seville, Spain, 12-14 November 2018; pp. 2382-2387. [CrossRef]

60. Domínguez Ruiz, V. Aplicación de los Sistemas de Información Geográfica (SIG) al Proyecto de Rehabilitación Arquitectónica y Urbana. Ph.D. Thesis, Universidad de Sevilla, Sevilla, Spain, 2016.

61. Martins, A. As Arquitecturas de Cister em Portugal. A Actualidade das Suas Reabilitações e a Sua Inserção No Território. Ph.D. Thesis, Universidad de Sevilla, Sevilla, Spain, 2011.

62. Sánchez Jiménez, F.J. Estudio Histórico-Técnico de los Molinos Hidráulicos de Alcalá de Guadaíra. Ph.D. Thesis, Universidad de Sevilla, Sevilla, Spain, 2015.

63. Mascort-Albea, E.J. Mapas para el Patrimonio: Caracterización Técnica de Las Iglesias Medievales de Sevilla Mediante Sistemas de Información Geográfica (SIG). Ph.D. Thesis, Universidad de Sevilla, Sevilla, Spain, 2018.

64. Guia Digital Instituto Andaluz del Patriminio Histórico (IAPH). Available online: https://guiadigital.iaph.es / (accessed on 17 July 2019).

65. Processo ACEF/0910/26421 Do Ciclo de Estudos Em Arquitectura; Covilhã, Portugal, 2012; Available online: https:/ / www.ugr.es / $\sim\{$ aepc/FECIES_16/LIBROCAPITULOXIII.pdf (accessed on 11 January 2021).

66. Martins, A. Curriculum Design: History of Portuguese Architecture and the Integrated Master Degree in Architecture. In Proceedings of the INTED 2018-12th International Technology, Education and Development Conference, Valencia, Spain, 5-7 March 2018; pp. 530-535. [CrossRef]

67. Martins, A. Portuguese Cistercian Heritage Research and Architectural Education. Heritage 2016, 2, $1139-1146$.

68. Barrows, H.S. A Taxonomy of Problem-based Learning Methods. Med. Educ. 1986, 20, 481-486. [CrossRef] [PubMed]

69. Garcia-Almirall, M.P.; Redondo Domínguez, E.; Valls Dalmau, F.; Corso Sarmiento, J.M. Experiencia Docente en la enseñanza de Sistemas de Información Geográfica en Arquitectura. In Proceedings of the 9th Iberian Conference on Information Systems and Technologies (CISTI), Barcelona, Spain, 18-21 June 2014; pp. 407-412. [CrossRef]

70. Bearman, N.; Jones, N.; André, I.; Cachinho, H.A.; DeMers, M. The Future Role of GIS Education in Creating Critical Spatial Thinkers. J. Geogr. High. Educ. 2016. [CrossRef] 